\title{
OCUPANDO PRAÇAS - DISPUTA DE DIREITOS ENTRE A SAÚDE E O LAZER
}

\author{
MENEZES, Ana Paula da R. \\ FAU-PROURB/UFRJ, e-mail: anapaularm@gmail.com \\ TÂNGARI, Vera \\ FAU-PROARQ/UFRJ, e-mail: vtangari@uol.com.br
}

\begin{abstract}
RESUMO
Esse trabalho é parte da dissertação desenvolvida no Mestrado em Arquitetura Paisagística do PROURB-UFRJ, e partiu das ocupações de praças por equipamentos públicos, na Zona Oeste da Cidade do Rio de Janeiro. Os espaços livres públicos devem ser preservados nas suas dimensões e funções originais, uma vez que são criados a fim de promover o lazer e o bem-estar da população de seu entorno, direitos previstos na constituição brasileira. Quando, por questões de necessidade, a ocupação desses espaços é determinada pelo poder público, que seja estudada de forma mais criteriosa e abrangente levando-se em consideração todos os conflitos inerentes a esse processo. Teve como objetivo geral verificar os impactos causados na inserção de equipamentos públicos em praças e propor diretrizes de projeto para futuras ocupações. A metodologia adotada para o desenvolvimento do estudo de caso foi composta por duas etapas: na primeira etapa foi feita a seleção das praças a serem estudadas; na segunda etapa foi realizado um mapeamento baseado em levantamentos históricos, físico-urbanísticos e dos usos e apropriações por parte da população. Como resultado elaboramos manual de procedimento quando da necessidade de ocupar esses espaços.
\end{abstract}

Palavras chave: intervenções, poder público, praças, ocupação, equipamentos públicos.

\begin{abstract}
This work is part of the dissertation developed in the Master in Landscape Architecture of PROURB-UFRJ, and started from squatting occupations by public equipment, in the West Zone of the City of Rio de Janeiro. Public spaces must be preserved in their original dimensions and functions, created in order to promote the leisure and well-being of the surrounding population, which are rights provided for in the Brazilian constitution. When, for reasons of necessity, the occupation of these spaces is determined by the public power, it is studied more carefully and comprehensively taking into account all the conflicts inherent in this process. Its general objective was to verify the impacts caused in the insertion of public equipment in squares and to propose design guidelines for future occupations. The methodology adopted for the development of the case study was composed of two stages: in the first the selection of the squares to be studied was made; in the second a mapping was carried out based on historical, physical-urbanistic surveys and of the uses and appropriations by the population. As a result, we elaborate procedure manual when the need to occupy these spaces.
\end{abstract}

Keywords: interventions, public power, squares, occupation, public equipment

\section{INTRODUÇÃO}

\subsection{Definição do problema}

"Encontramos um terreno!" Com sorriso nos olhos os funcionários da prefeitura traziam a novidade. Que "terreno" era esse? Uma praça. Por que uma praça? Por que se desfazer de um espaço que fora destinado ao lazer da

MENEZES, A. P. R.; PTÂNGARI, V. Ocupando Praças - Disputa de Direitos entre a Saúde e o Lazer. In: SIMPÓSIO BRASILEIRO DE QUALIDADE DO PROJETO NO AMBIENTE CONSTRUÍDO, 6., 2019, Uberlândia. Anais... Uberlândia: PPGAU/FAUeD/UFU, 2019. p. 164-180. DOI https://doi.org/10.14393/sbqp19017. 
comunidade do entorno para se instalar um equipamento público mesmo que seja destinado a essa mesma população? Muitas vezes não havia mesmo outra opção. Muitas vezes "essas praças" não passavam de lotes destinados a praças, mas nunca efetivamente utilizados como local de lazer e convívio social. Outras vezes, o espaço era utilizado pelos moradores tendo inclusive uma agenda social rica em eventos.

O Quadro 1 apresenta esse processo ao descrever a relação de praças estudadas cujas áreas foram desafetadas para receberem equipamentos municipais para funcionamento de Clínicas da Família. Nele estão relacionados: os registros de criação das praças através dos Projetos de Alinhamento (PAL); as áreas originalmente destinadas às praças; as áreas desafetadas e os decretos relativos; o percentual entre as áreas desafetadas e a áreas originais das praças e as áreas remanescentes.

Quadro 1 - Áreas das praças antes e após as implantações das Clínicas da Família

\begin{tabular}{|l|l|l|l|l|}
\hline \multicolumn{1}{|c|}{ BAIRRO } & \multicolumn{1}{c|}{ PRAÇA } & \multicolumn{1}{c|}{ PAL } & \multicolumn{2}{c|}{ ÁREA PAL } \\
\hline BANGU & Lealdina Muniz & PAL 35.478 & 5210 & $\mathrm{~m}^{2}$ \\
\hline CAMPO GRANDE & Pedro Veloso da Silveira & PAL 38228 & 6674,52 & $\mathrm{~m}^{2}$ \\
\hline CAMPO GRANDE & Sangradouro & PAL 36717 & 2574 & $\mathrm{~m}^{2}$ \\
\hline REALENGO & Marobá & PAL 18249 & 5990 & $\mathrm{~m}^{2}$ \\
\hline
\end{tabular}

\begin{tabular}{|l|l|l|l|l|l|l|l|}
\hline \multicolumn{1}{|c|}{ BAIRRO } & \multicolumn{1}{c|}{ PRAÇA } & \multicolumn{1}{c|}{ DECRETO } & \multicolumn{2}{c|}{ ÁREA DESAFETADA } & \multicolumn{2}{c|}{ ÁREA ATUAL } \\
\hline BANGU & Lealdina Muniz & $38215 / 2013$ & 2334,1 & $\mathrm{~m}^{2}$ & 0,448 & 2875,9 & $\mathrm{~m}^{2}$ \\
\hline CAMPO GRANDE & Pedro Veloso da Silveira & $41903 / 2016$ & 2182,62 & $\mathrm{~m}^{2}$ & 0,327 & 4491,9 & $\mathrm{~m}^{2}$ \\
\hline CAMPO GRANDE & Sangradouro & $41413 / 2016$ & 2574 & $\mathrm{~m}^{2}$ & 1 & 0 & $\mathrm{~m}^{2}$ \\
\hline REALENGO & Marobá & PROJETO* & 1401,3 & $\mathrm{~m}^{2}$ & 0,2339 & 4588,7 & $\mathrm{~m}^{2}$ \\
\hline
\end{tabular}

Fonte: Elaborado pela autora, 2017

O objetivo da pesquisa foi discutir o papel e a importância das praças na atualidade, tanto para a cidade quanto para o cidadão. Com base no argumento de autores que se dedicaram ao tema (ROBBA e MACEDO, 2002; QUEIROGA, 2011), defende-se a necessidade de um maior cuidado na inserção de equipamentos públicos na cidade em oposição a uma política pública que elege interesses políticos em detrimentos de outros interesses da coletividade.

O impacto da construção de equipamentos públicos em espaços livres públicos geram grandes rupturas nos ambientes urbanos já consolidados muitas vezes provocando retirada de elementos paisagísticos e de espaços de convivência importantes.

\subsection{Justificativa}

Segundo Queiroga (2001), é preciso salientar a importância das praças tanto sob o ponto de vista da qualidade ambiental urbana quanto como espaço de convivência e trocas, principalmente no que tange às relações sociais, base do desenvolvimento do indivíduo como parte de um coletivo.

Ainda que reconheçamos os impactos negativos que acompanham esse tipo de intervenção física nos espaços urbanos, a pesquisa pretendeu também verificar os impactos positivos sobre seu entorno imediato comparando seus benefícios potenciais e sua importância para mudanças nas cidades. É preciso 
compreender o fenômeno para instrumentalizar o poder público com 0 ferramental necessário a fim de possibilitar o ressurgimento da praça como local de convergência.

\section{FUNDAMENTAÇÃO}

A fundamentação desse artigo está dividida em três itens relativos à temática abordada na pesquisa com uma visão multidisciplinar. Compreendeu a leitura de autores que se dedicaram a:

- Questões jurídicas: a partir da visão do direito sobre a função social da propriedade pública;

- Espaço de convivência: a fim de entender como se dá essa relação do indivíduo com os espaços livres de lazer e vivência social;

- Aspectos espaciais: forma, projeto e apropriação.

\section{METODOLOGIA}

A metodologia adotada foi estudo de caso tendo sido desenvolvida em duas etapas: a primeira etapa foi a seleção das praças; a segunda etapa foi um mapeamento baseado em levantamentos históricos, espaciais e dos usos e apropriações, avaliação ambiental e dos aspectos biofísicos das praças.

A seleção foi baseada nas últimas ocupações pelo poder público na Zona Oeste da cidade de Rio de Janeiro. A pesquisa se estende por três bairros Bangu, Campo Grande e Realengo, totalizando quatro praças.

Os critérios para a escolha das praças dentro do universo inicial levaram em consideração as seguintes questões:

- Praça parcialmente ocupada e com características de praça - foram selecionadas duas que atendiam a esse critério;

- Praça parcialmente ocupada, mas cuja área remanescente apenas contemplava quadra/campo de futebol - seis praças atendiam ao critério, a praça selecionada envolve intensa atividade esportiva;

- Praça totalmente ocupada.

De acordo com Zeisel (1984), a metodologia adotada para a segunda parte do trabalho é de cunho qualitativo, baseado em três vertentes: a coleta de dados sobre os espaços selecionados; o levantamento dos contextos físicourbanísticos; a leitura cognitiva.

Na etapa de leitura cognitiva enfocou-se a significância das praças para os moradores e frequentadores, realizada a partir dos dados coletados junto à população usuária das praças, por meio de entrevistas aplicadas in loco. 0 questionário foi elaborado tendo como objetivo deixar o entrevistado livre para responder as questões (perguntas abertas). Procurou-se variar nos tipos de entrevistados tanto quanto ao gênero como idade a fim de garantir uma visão diversificada sobre a praça e a ocupação pela Clínica da Família.

\subsection{Estudos de Caso: Quatro Praças Ocupadas}

A pesquisa analisou quatro praças ocupadas e localizadas na Área de Planejamento 5, situadas na Zona Oeste do Rio de Janeiro (Figuras 1 e 2). 


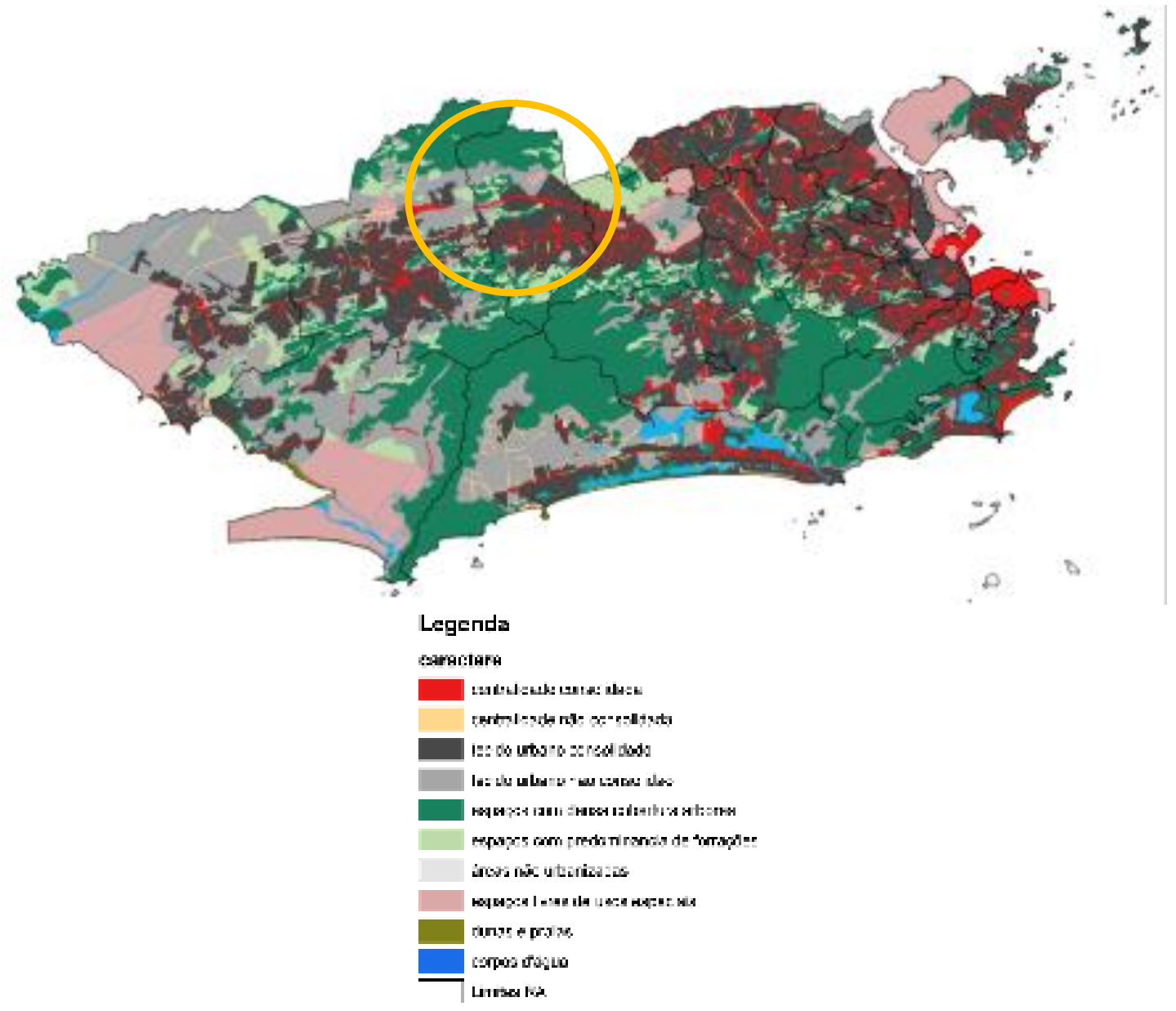

Figura 1 - Localização do recorte de estudo na cidade do Rio de Janeiro Fonte: Mapeamento de tecidos urbanos e centralidades - SEL-RJ, 2017

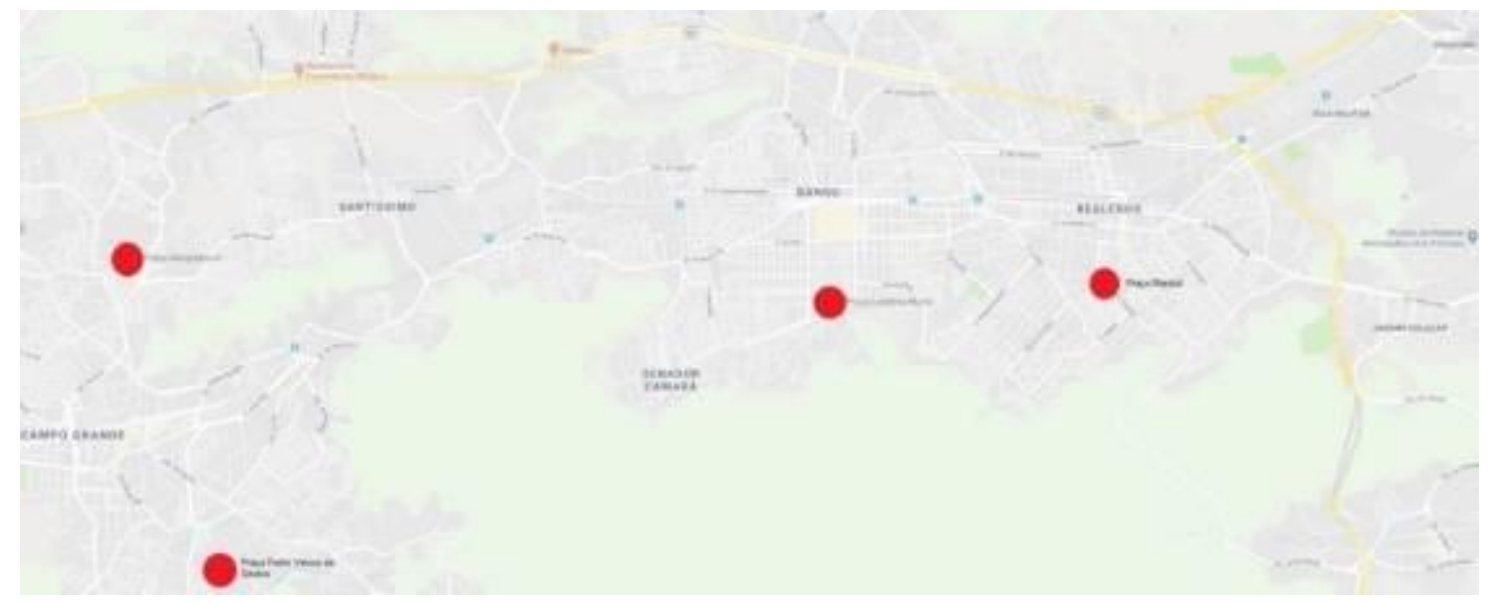

Figura 2 - Localização das quatro praças objeto de estudo e pesquisa

Fonte: Google Earth, 2017

Nos últimos anos de governo do então prefeito Eduardo Paes, (gestão 20122016), foram lançadas licitações a fim de construir 40 Clínicas da Família no município, sendo 28 delas na zona oeste, especificamente nas Áreas de Planejamento - AP 4 e 5 (Figura 3). Desse total, 14 seriam implantadas na AP 5. Dentre elas, oito são atualmente situadas em praças, seja na totalidade de suas dimensões ou em pequenas ou grandes proporções. 


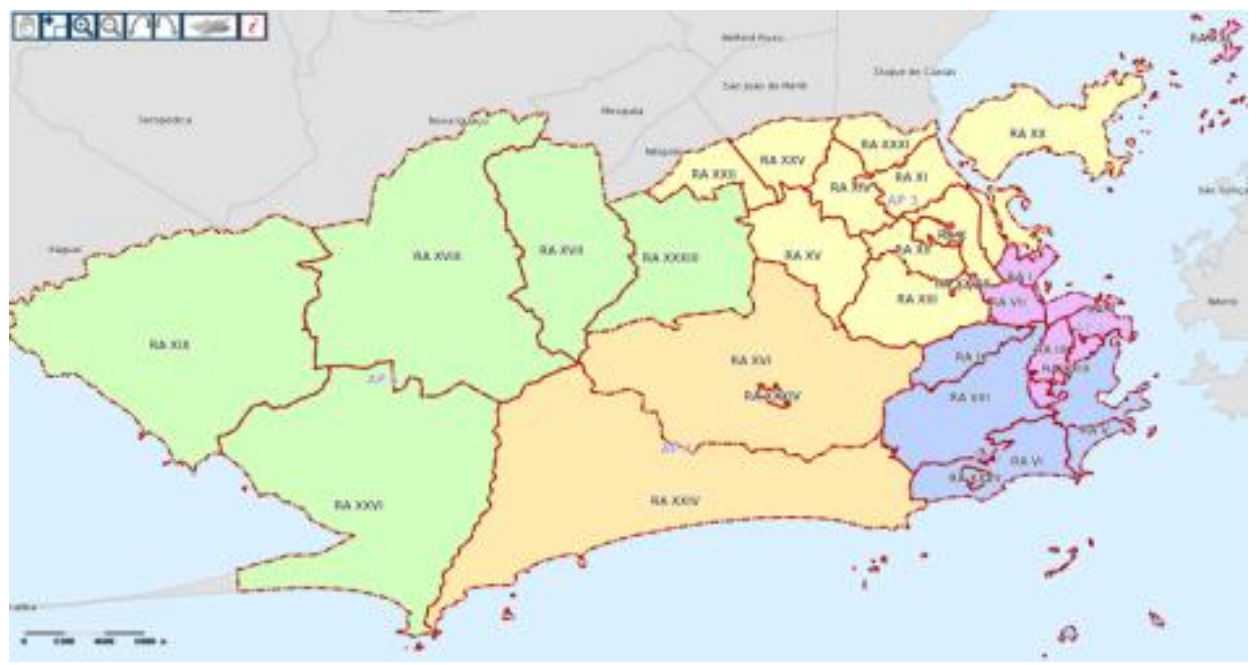

Figura 3 -Áreas de Planejamento: em verde a Área de Planejamento 5

Fonte: PCRJ, Armazém de Dados, 2017

Apresentamos a caracterização de cada área objeto desse estudo, a fim de entender os possíveis impactos decorrentes da implantação de equipamentos públicos de saúde em áreas de lazer.

Das praças analisadas, a Praça Lealdina Muniz é a que mais possui características predominantemente de área de lazer comunitário e para todas as faixas etárias, gêneros e tipos de interesses (Figura 4)

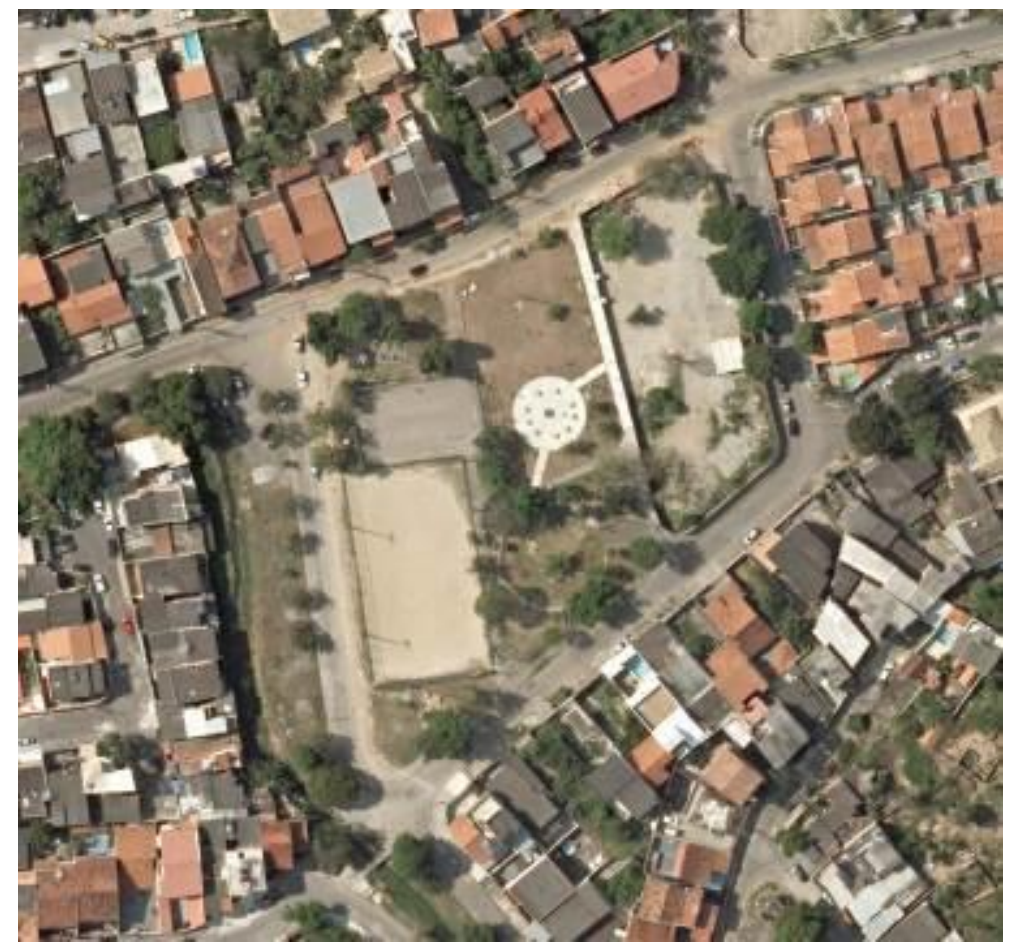

Figura 4 - Praça Lealdina Muniz em Bangu

Fonte: Foto da autora, outubro de 2017.

Igualmente com características marcantes de área de lazer adequada a todas as faixas etárias, a Praça Pedro Veloso possui áreas densamente arborizadas, equipamentos de lazer infantil, quadra poliesportiva, mesas e bancos (Figura 5). A clínica, ainda em construção, ocupará um terço da área da praça. Para implantação da clínica foi aproveitada uma área que era utilizada como campinho de futebol. 


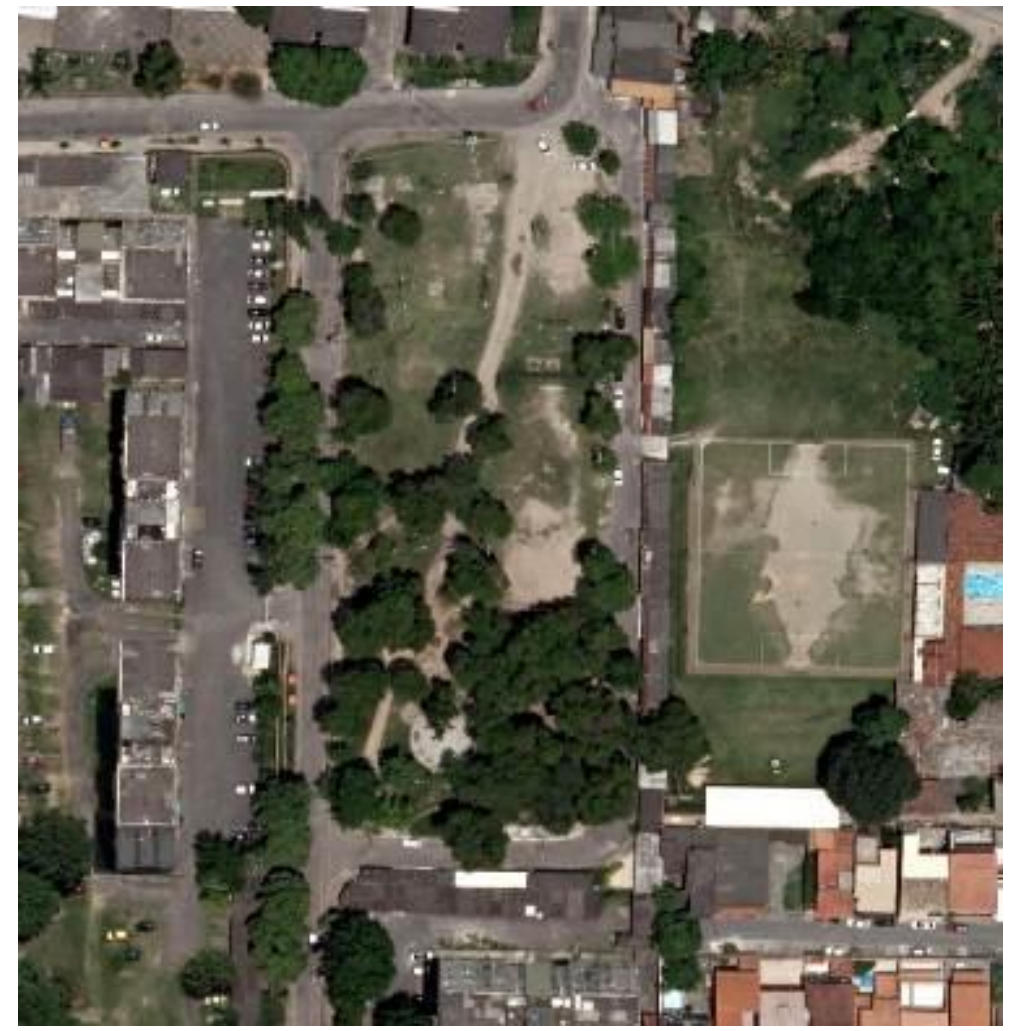

Figura 5 - Praça Pedro Veloso da Silveira em Campo Grande Fonte: Foto da autora, outubro de 2017

Caso mais grave de ocupação pelo poder público de áreas destinadas ao lazer, a Praça Sangradouro deixou de existir (Figura 6). Sua superfície de $2.574 \mathrm{~m}^{2}$ foi totalmente ocupada pela Clínica da Família que atualmente conta com espaços internos ajardinados e cercados.

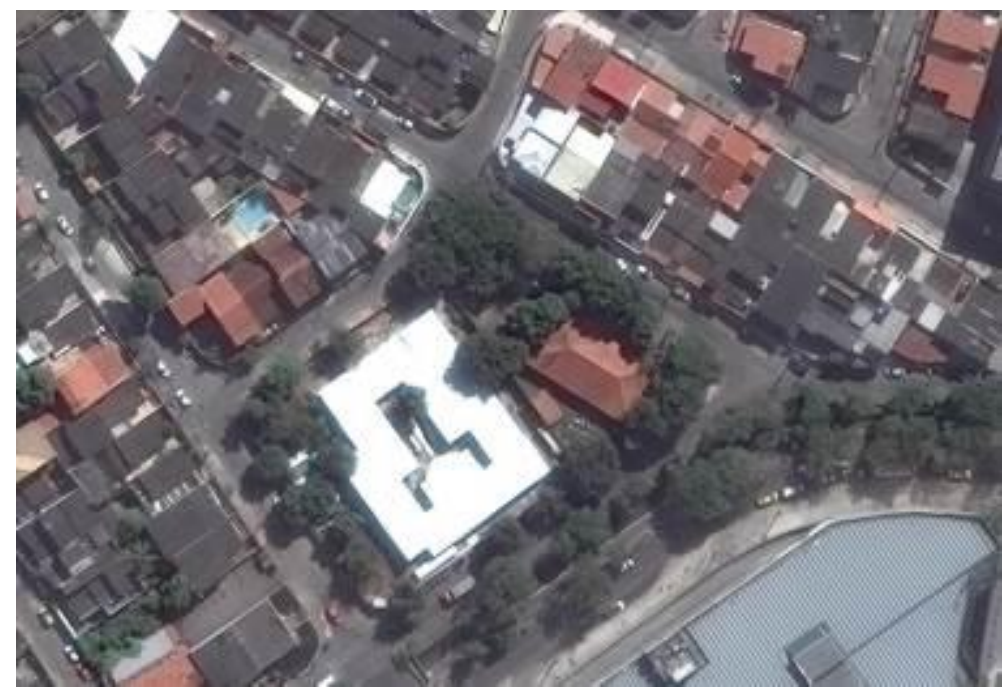

Figura 6 - Implantação da clínica Arthur Zanetti em Na Praça Sangradouro Fonte: Foto da autora, outubro de 2017.

No caso da Praça Marobá, ou Campo do Periquito, conforme é reconhecida até mesmo pelas ferramentas de busca (Google Maps), os moradores de Realengo conseguiram derrubar outras duas praças sendo essa a terceira opção para a implantação da Clínica (Figura 7).

Também possui campo oficializado, gradeado e iluminado por holofotes, porém seu estado de conservação beira ao abandono. No entanto nos finais de semana o lugar é frequentado pelos moradores que organizam partidas de 
futebol. O lugar também é dotado de vestiários como apoio às atividades ali realizadas.

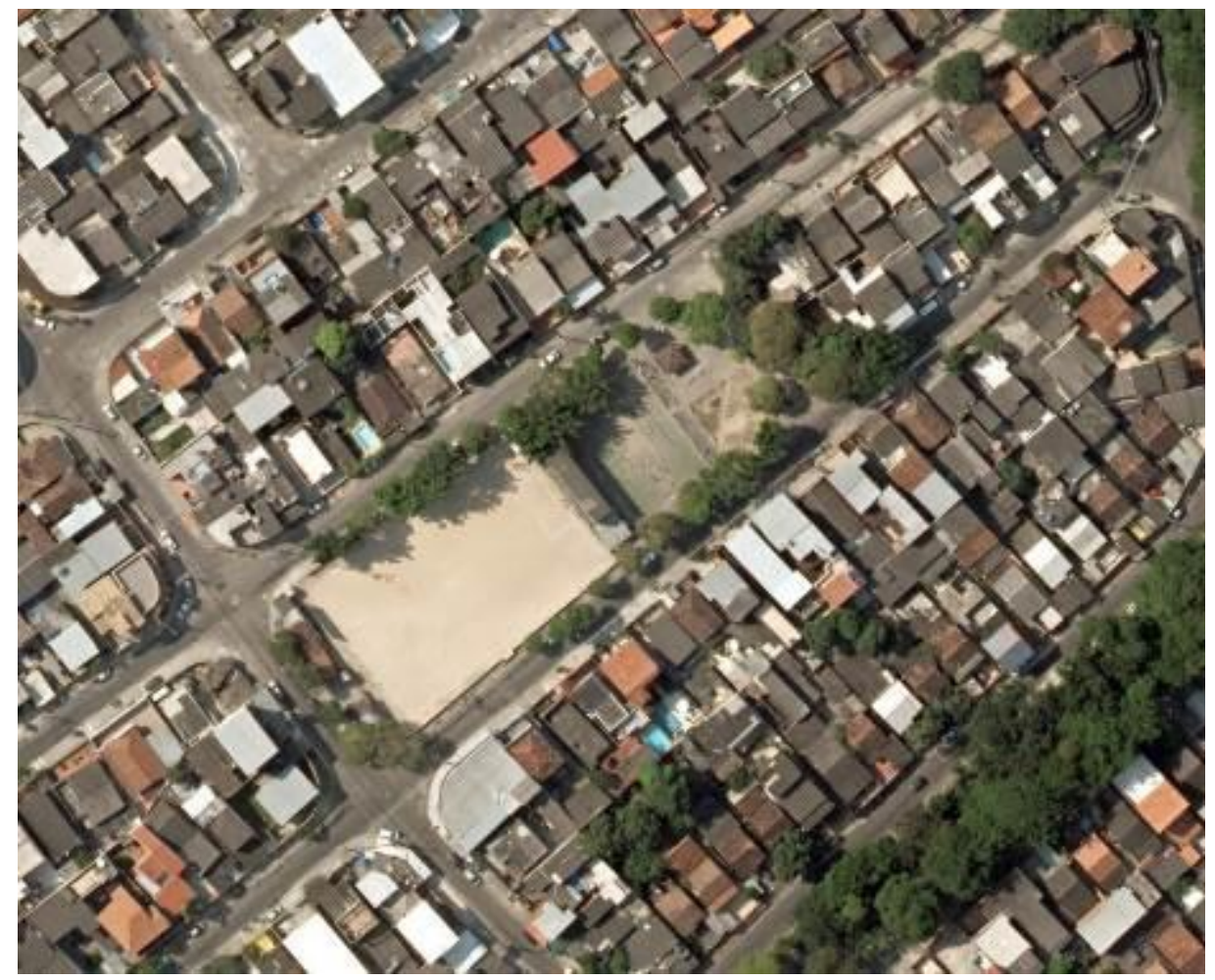

Figura 7 - Praça Marobá, ou Campo do Periquito

Fonte: Foto da autora, outubro de 2017.

A implantação da Clínica não avançou para a área do campo justamente pela singularidade do mesmo ser cercado, ou seja, sua faixa de domínio é delimitada por elementos que geram mais segurança.

\section{RESULTADOS E DISCUSSÃO}

\subsection{Resultados preliminares da pesquisa de campo}

Grande parte dos entrevistados se mostrou favorável à ocupação das praças por Clínicas da Família, mesmo que elas não estejam funcionando corretamente. No entanto muitos afirmaram que era melhor não ter a clínica, pois enquanto a clínica ineficiente não existia eles conseguiam atendimento em outras unidades, mesmo tendo que se deslocar para outra região no bairro. Atualmente, esse atendimento não é mais possível, uma vez que o Programa Saúde da Família divide as regiões de atendimento. Não obstante foi uma surpresa para a pesquisa o fato de que boa parte dos entrevistados achar boa a ocupação mesmo não sabendo explicar os motivos. 

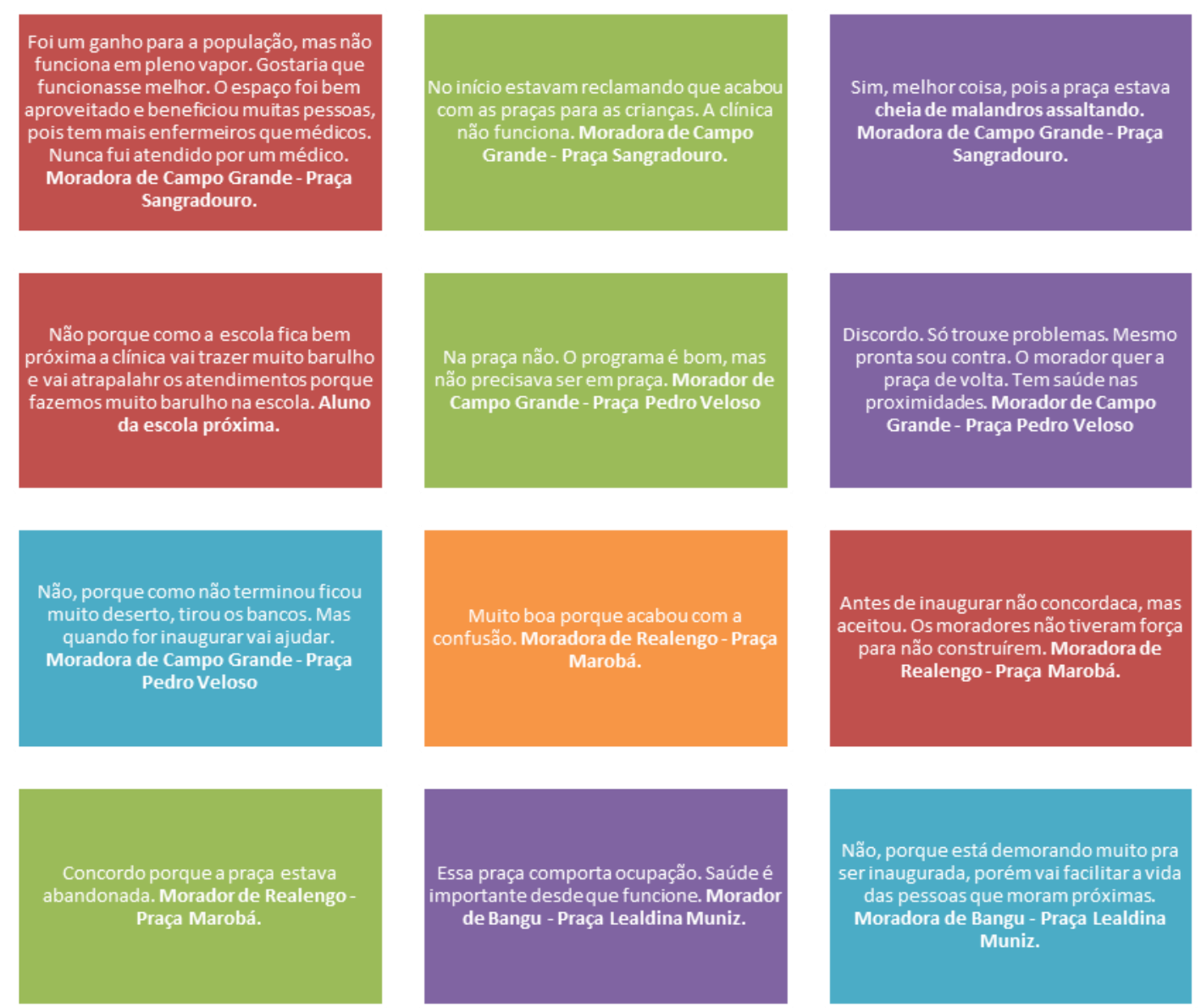

Quadro 2 - Depoimentos mais significativos com relação à ocupação das praças por Clínicas da Família

Fonte: Autora, 2018

A ocupação de praças passou a ser objeto de indagações por parte dos moradores de áreas adjacentes às mesmas. Algumas comunidades fortes conseguiram modificar essa ocupação. Os relatos do quadro acima refletem bem o que encontramos nas conversas preliminares para elaboração do presente trabalho onde alguns moradores se queixaram da falta de diálogo entre o poder público e a comunidade que ele se diz atender.

\subsection{Questões de Convivência}

Segundo Amaral, Sanchez e Bienenstein (2012) "uma grande parcela pobre da população, situada a margem de direitos, encontra-se hoje nas áreas urbanas expondo paisagens onde se reconhece a urbanização desigual gerada pelos processos de desenvolvimento". Segundo as autoras,

No campo das disputas sobre como transformar as cidades, os fins e os meios em jogo constituem um amplo cabedal de ideias, técnicas, projetos, intervenções, instrumentos jurídicoadministrativos etc. que são permeados por ideologias e opções políticas. Desde um planejamento normativo de caráter sistêmico, recentemente "enriquecido" pelos processos participativos, até a estratégia de realização de obras pontuais como instrumento de estímulo à revitalização da cidade, elaborada ideologicamente como "acupuntura urbana", cada concepção reivindica para si a capacidade de promover o desenvolvimento - e não é demais lembrar que para cada concepção a palavra desenvolvimento assumirá um sentido distinto. 
As regiões metropolitanas crescem através de loteamentos de grandes áreas que consequentemente geram espaços livres de edificações, sendo alguns destinados a praças e outros a equipamentos públicos, tais como escolas e equipamentos de saúde. Segundo Queiroga (2001),

Isso resulta em manchas urbanas amorfas, paisagens desinteressantes, pobres em espaços livres normalmente adequados ao lazer e convívio, pobres de valorização de sítio, onde a caótica ocupação individual de cada lote, feita sem respeitar o entorno, leva a uma homogeneização e a uma monótona paisagem.

Percebe-se uma despreocupação alarmante com a produção de paisagem urbana oriunda das intervenções que foram ocorrendo ao longo dos anos de forma desordenada sob o ponto de vista do planejamento na macro escala.

Se por um lado a instalação do equipamento público de saúde pode estimular novas dinâmicas de transformação, por outro lado há dúvidas quanto aos seus impactos. Enquanto a escolha dos locais para implantação dos equipamentos públicos não levar em consideração as dinâmicas préexistentes no território nem contar com a participação da comunidade, o investimento pode ser destinado ao fracasso ou perder sua legitimidade (MENEZES, MENDONÇA, TÂNGARI, 2018).

\subsection{Questōes do Direito}

Que direito é mais importante? Existe um direito mais importante que o outro? Podemos abrir mão de um direito para proporcionar outro? Como encarar o fato do poder público se utilizar do seu direito de propriedade para construir uma clínica (direito à saúde) em praça existente, mas reduzindo ou eliminando o direito ao lazer de uma comunidade ou até mesmo de um bairro?

Com tantos conflitos de interesses e de direitos, alguns fundamentais e constitucionais, caberia valer-se do recurso jurídico conhecido como "ponderação de direitos", fórmula criada por Robert Alexy e que segundo Silveira (2013),

[...] consiste no método necessário ao equacionamento das colisões entre princípios, em que se busca alcançar um ponto ótimo, em que a restrição a cada um dos direitos fundamentais envolvidos seja a menor possível, na medida exata à salvaguarda do direito contraposto. [...] as restrições impostas aos direitos fundamentais em disputa devem ser arbitradas mediante o emprego do princípio da proporcionalidade, devendo o julgador buscar um ponto de equilíbrio entre os interesses em jogo [...]

O objetivo, ao utilizar-se dos recursos da área jurídica, foi salientar que para administrar minimamente a cidade é preciso compreender princípios básicos do direito. Outrossim, podemos afirmar que são relativamente numerosas as situações de entrechoque de direitos igualmente relevantes, quando considerados de maneira abstrata, de modo que a "solução" da situação de conflito requer a consideração de circunstâncias de fato, dentre outras variáveis admitidas na literatura jurídica.

No entanto é de fundamental importância para o estudo perceber como o administrador público desrespeita suas próprias leis, pois embora a Lei Orgânica do Município determine destinação específica de praças como bem a ser preservada, conforme descrito abaixo, veremos que essa 
determinação vem sendo alterada:

Na Lei Orgânica do Município do Rio de Janeiro:

Art. 235 - As áreas verdes, praças, parques, jardins e unidades de conservação são patrimônio público inalienável, sendo proibida sua concessão ou cessão, bem como qualquer atividade ou empreendimento público ou privado que danifique ou altere suas características originais.

Muitas vezes essas praças eram o único espaço livre público "disponível" para construção do equipamento público com a função social destinada à saúde dos cidadãos.

Da necessidade de organizar o espaço habitável, o campo do Direito Urbanístico foi moldado a fim de legitimar as intervenções do Poder Público na propriedade e na cidade, com o objetivo de garantir a supremacia do interesse coletivo, tendo o papel de configurar o Direito de Propriedade do solo urbano, definindo o seu conteúdo em cada situação concreta presente na cidade, tendo por base o Plano Diretor. Quando a ação jurídica se refere a uma propriedade pública urge estabelecer critérios mais rígidos para a utilização desses espaços que, por serem de caráter coletivo, deveriam ter sua utilização definida pela sociedade.

Seguindo as orientações das consultorias realizadas durante essa pesquisa com profissionais da área do Direito Urbanístico, e salvaguardando as diferenças existentes entre o Direito Romano base do Direito Brasileiro e o Direito Americano que se utiliza do método jurídico de ponderação, e entendendo que existe a necessidade de uma adequação à técnica conhecida como ponderação de direitos, uma vez que os dois direitos em conflito (saúde e lazer) são direitos constitucionais de mesma hierarquia, construiu-se um conceito instrumental inspirado na técnica de ponderação de direitos, questionando:

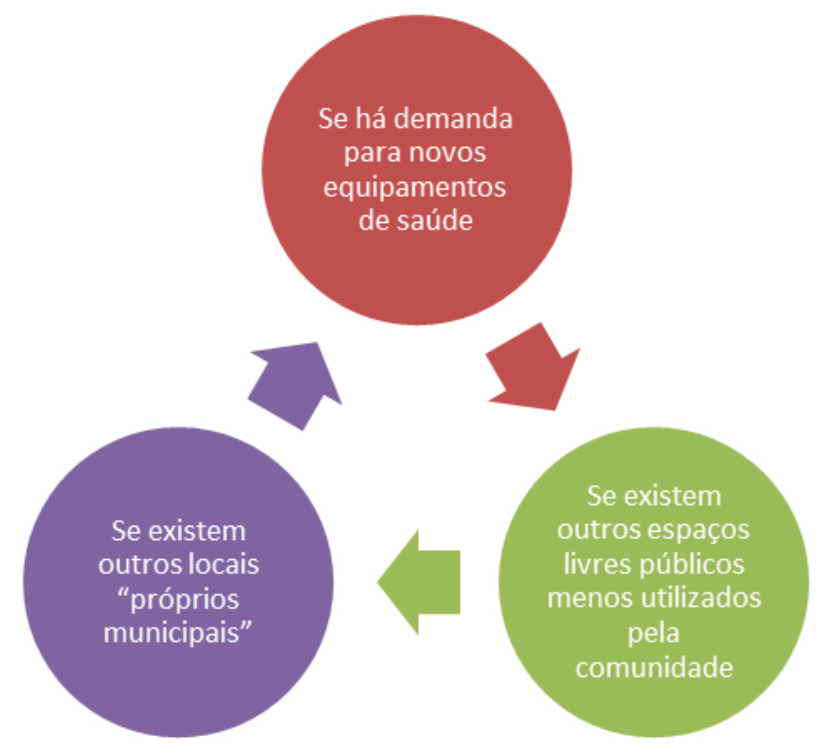

Figura 8 - Primeira fase da ponderação

Fonte: Elaborado pela autora, 2018

Vale ressaltar que a ponderação de interesses consiste no "método necessário ao equacionamento das colisões entre princípios da Lei maior, onde se busca alcançar um ponto ótimo, em que a restrição a cada um dos bens jurídicos de estatura constitucional envolvidos seja a menor possível, na medida exata necessária à salvaguarda do bem jurídico contraposto" (SARMENTO, 2003). 


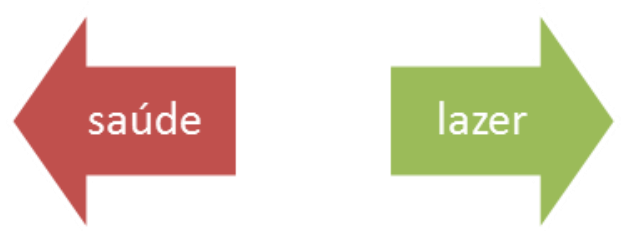

Figura 9 - Conflito de direitos

Fonte: Elaborado pela autora, 2018

A demanda de novas unidades da rede de saúde municipal é apontada pela Secretaria Municipal de Saúde que indica a área de atuação que necessita de ampliação de atendimento. No caso das Clínicas da Família, o sistema Saúde da Família conta com equipes que se deslocam até as residências dos atendidos e a distância entre a unidade base e a residência deve ser a menor possível para agilizar o atendimento e ampliar o número de atendidos.

Após a constatação de que há demanda por novo equipamento, de que não há outros locais "próprios municipais" destinados à construção de equipamento público e que não há outras praças cuja utilização seja precária, passamos a questionar se existem:

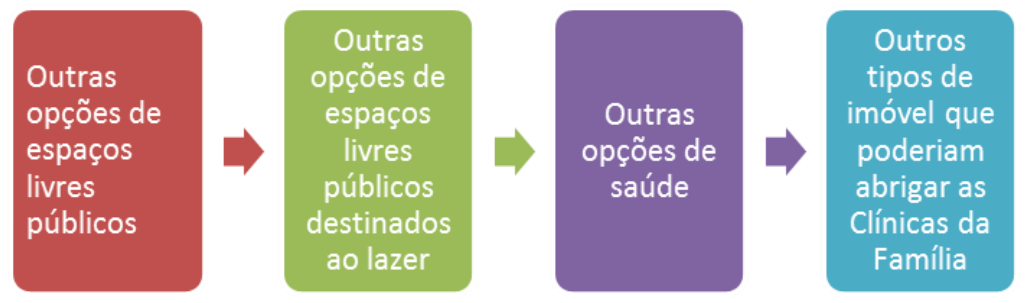

Figura 10 - Segunda fase da ponderação

Fonte: Elaborado pela autora, 2018

Esgotadas as opções de ponderações elencadas, logo após a decisão de se implantar o equipamento urbano na praça, a primeira ação seria a aplicação da técnica que compreende três passos, conforme Figura 11.
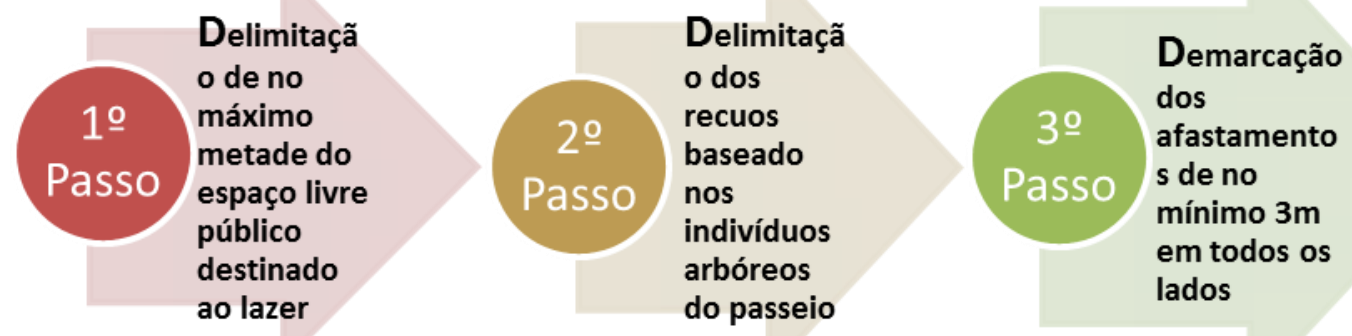

Figura 11 - Técnica dos "Três 'Ds"

Fonte: Elaborado pela Autora, outubro de 2018

Aplicando o primeiro passo - Delimitação do terreno: a área destinada ao novo equipamento público em área de praça não poderá ultrapassar o limite de $50 \%$ da área de lazer daquela comunidade. 


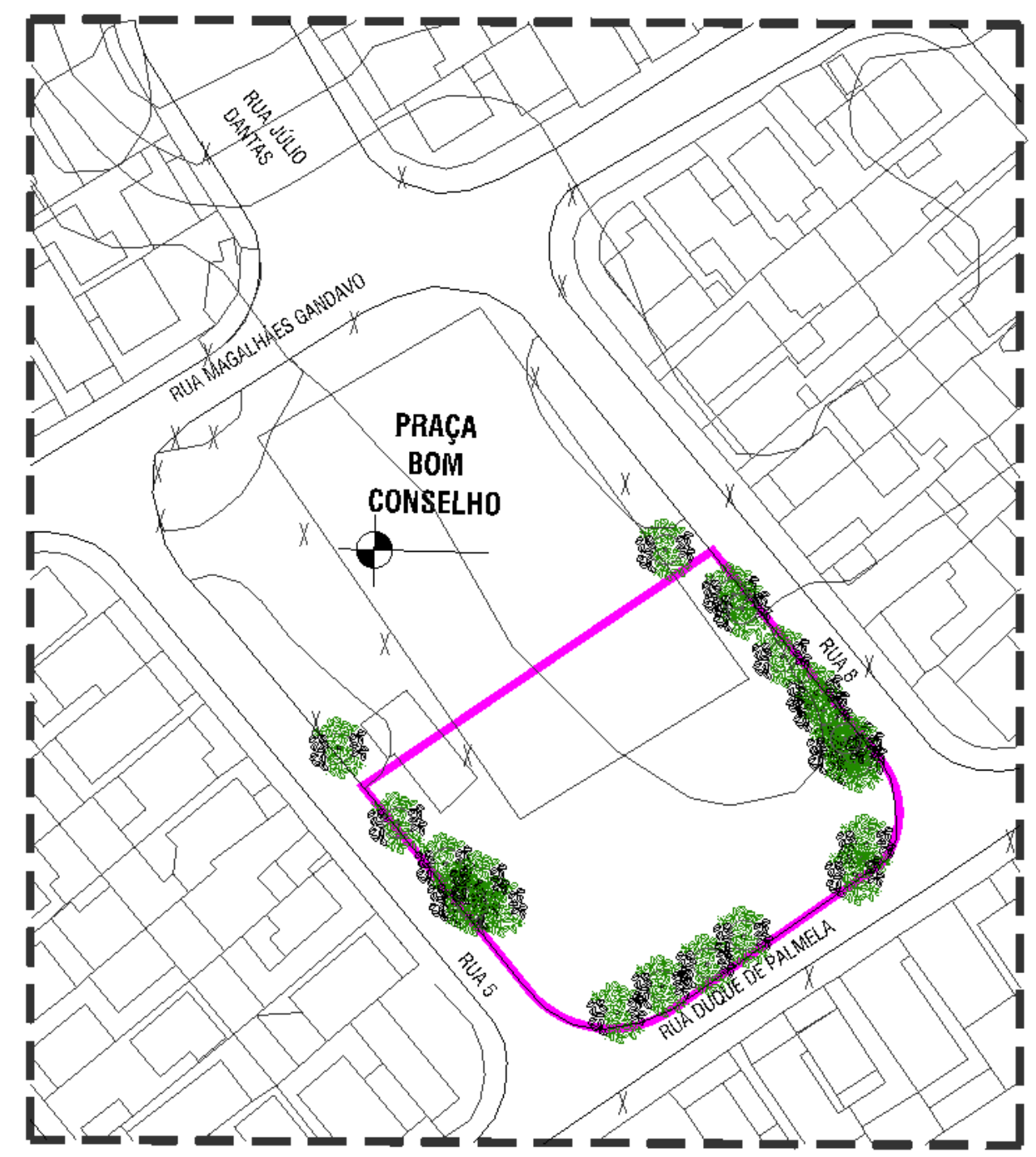

Figura 12 - $1^{\circ}$ passo - delimitação de metade do espaço livre público destinado ao lazer.

Fonte: Arte sobre cadastral - Autora (outubro de 2018)

Cumprida essa diretriz passamos a determinação do recuo e consequentemente a demarcação do limite real do terreno. Para tal toma-se por base a localização dos elementos arbóreos existentes no passeio adotando as medidas de 1,50 a partir do seu centro para determinação do raio da gola e mais 1,50 para o passeio totalizando, na maioria dos casos, em $3 \mathrm{~m}$ de largura total do passeio no mínimo nos trechos onde a árvore se encontra mais próxima ao meio-fio. 


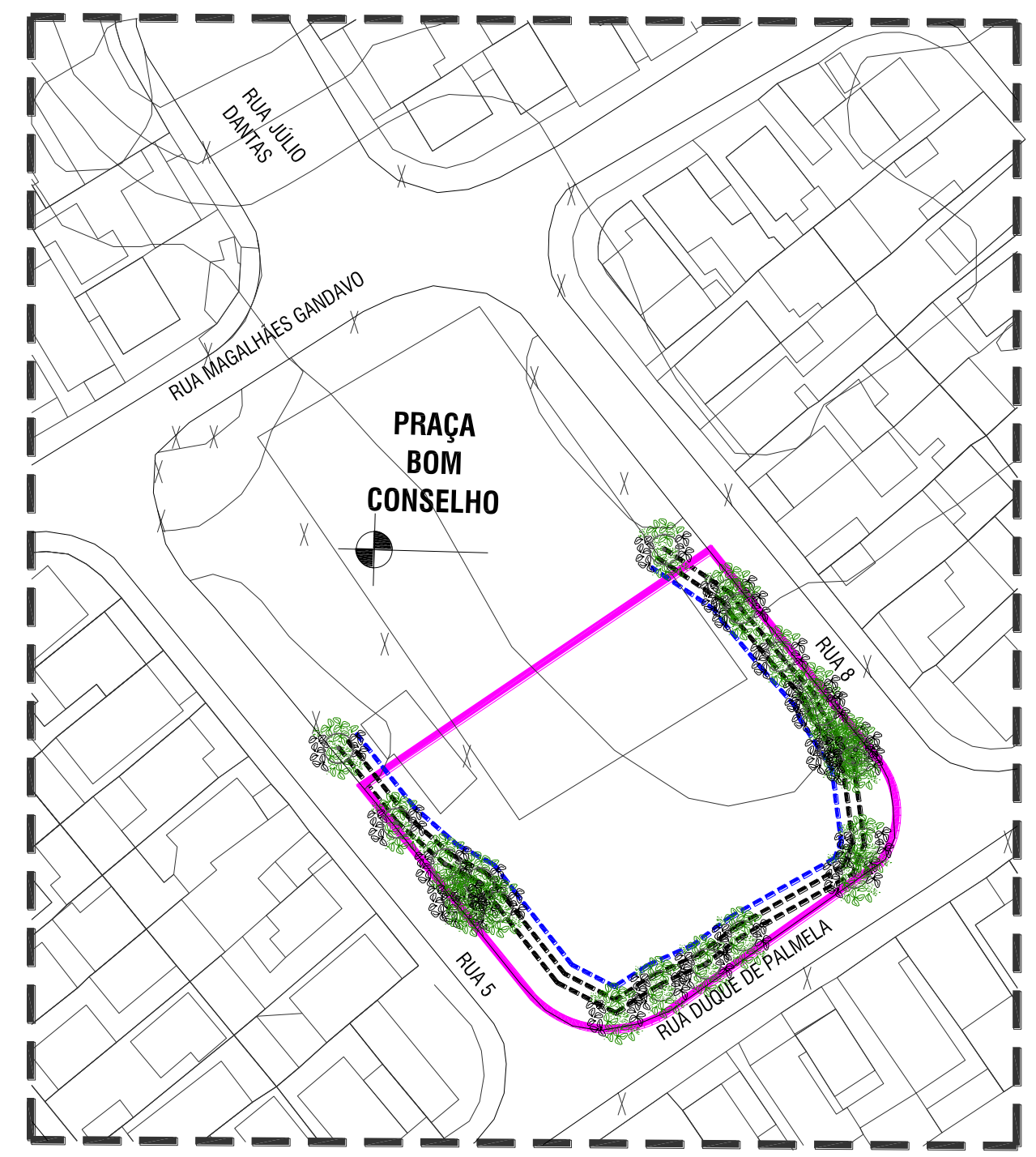

Figura 13 - $2^{\circ}$ passo - delimitação das distâncias da gola e do passeio. Fonte: Arte sobre cadastral - Autora (outubro de 2018)

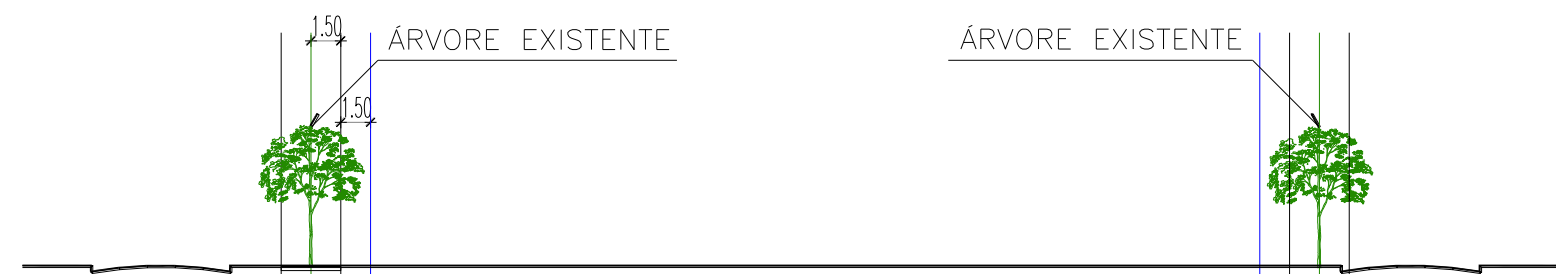

Figura 14 - $2^{\circ}$ passo - delimitação das distâncias da gola e do passeio - cortes Fonte: Arte sobre cadastral - Autora (outubro de 2018)

Após a delimitação desses limites mínimos traçamos um lote retilíneo utilizandose a pior situação. Sendo assim o lote ficaria com uma configuração conforme figura 13. 


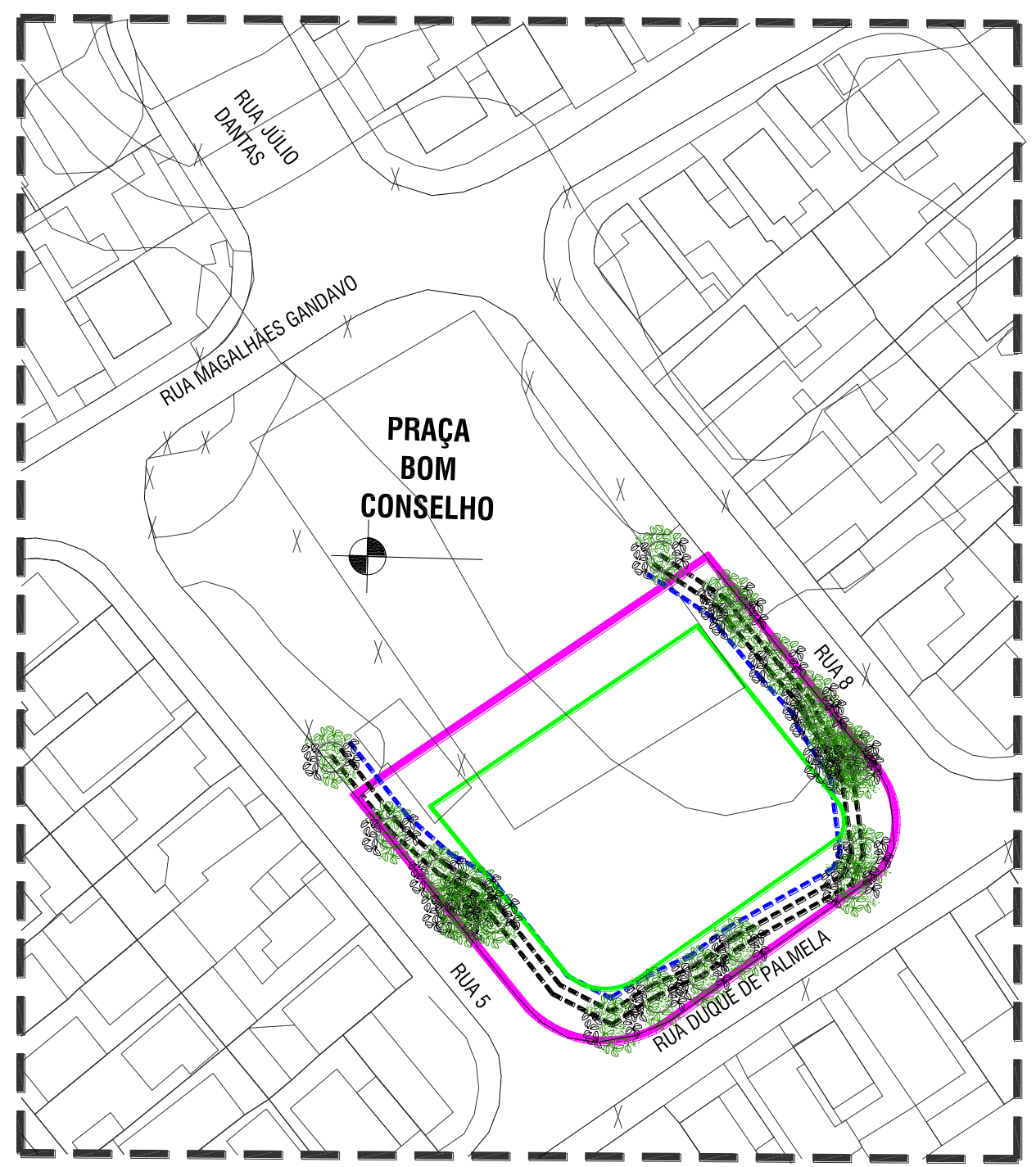

Figura 15 - $2^{\circ}$ passo - delimitação dos recuos baseado nos indivíduos arbóreos do passeio.

Fonte: Arte sobre cadastral - Autora (outubro de 2018)

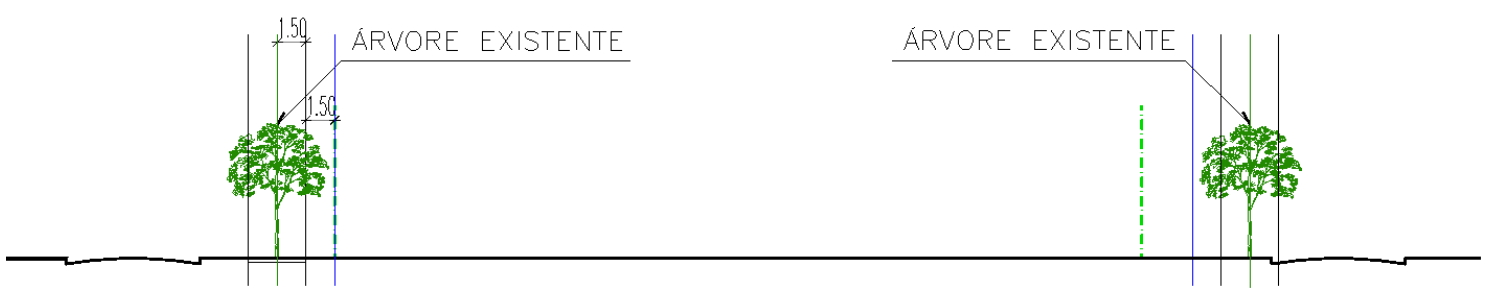

Figura 16 - $2^{\circ}$ passo - delimitação dos recuos baseado nos indivíduos arbóreos do passeio - cortes

Fonte: Arte sobre cadastral - Autora (outubro de 2018)

Após essa delimitação do terreno, o segundo passo inclui a demarcação dos afastamentos de no mínimo $3 \mathrm{~m}$ em todos os lados (frente, fundos e laterais) de forma a deixar o equipamento afastado das divisas. Desta forma poderiam ser atendidos os coeficientes de ocupação e de permeabilidade do solo. 


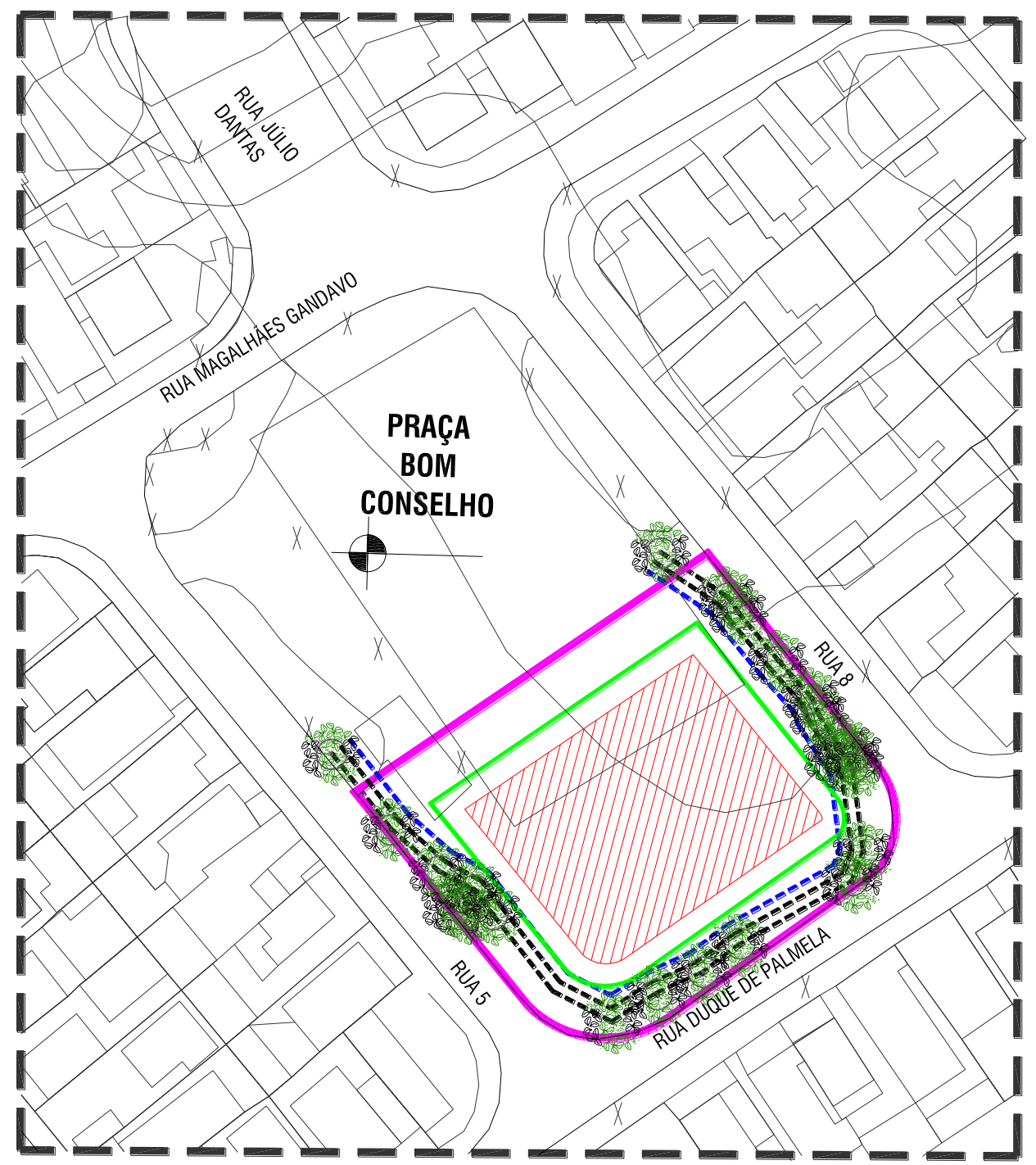

Figura 17 - $3^{\circ}$ passo - demarcação dos afastamentos mínimos de $3 \mathrm{~m}$. Fonte: Arte sobre cadastral - Autora (outubro de 2018)

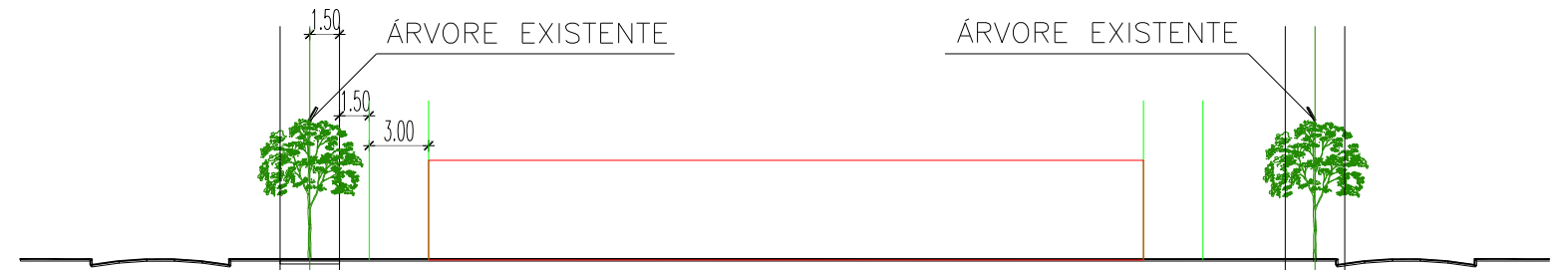

Figura 18 - $3^{\circ}$ passo - demarcação dos afastamentos mínimos de $3 \mathrm{~m}$ - cortes Fonte: Arte sobre cadastral - Autora (outubro de 2018)

Numa comparação entre a adoção das diretrizes sugeridas nessa pesquisa e a real implantação da Clínica Rogério Pinto da Mota na Praça Bom Conselho verificou-se que houve uma redução de apenas $8 \%$ de área de ocupação do solo, sem contar o átrio, conforme figura 19. 


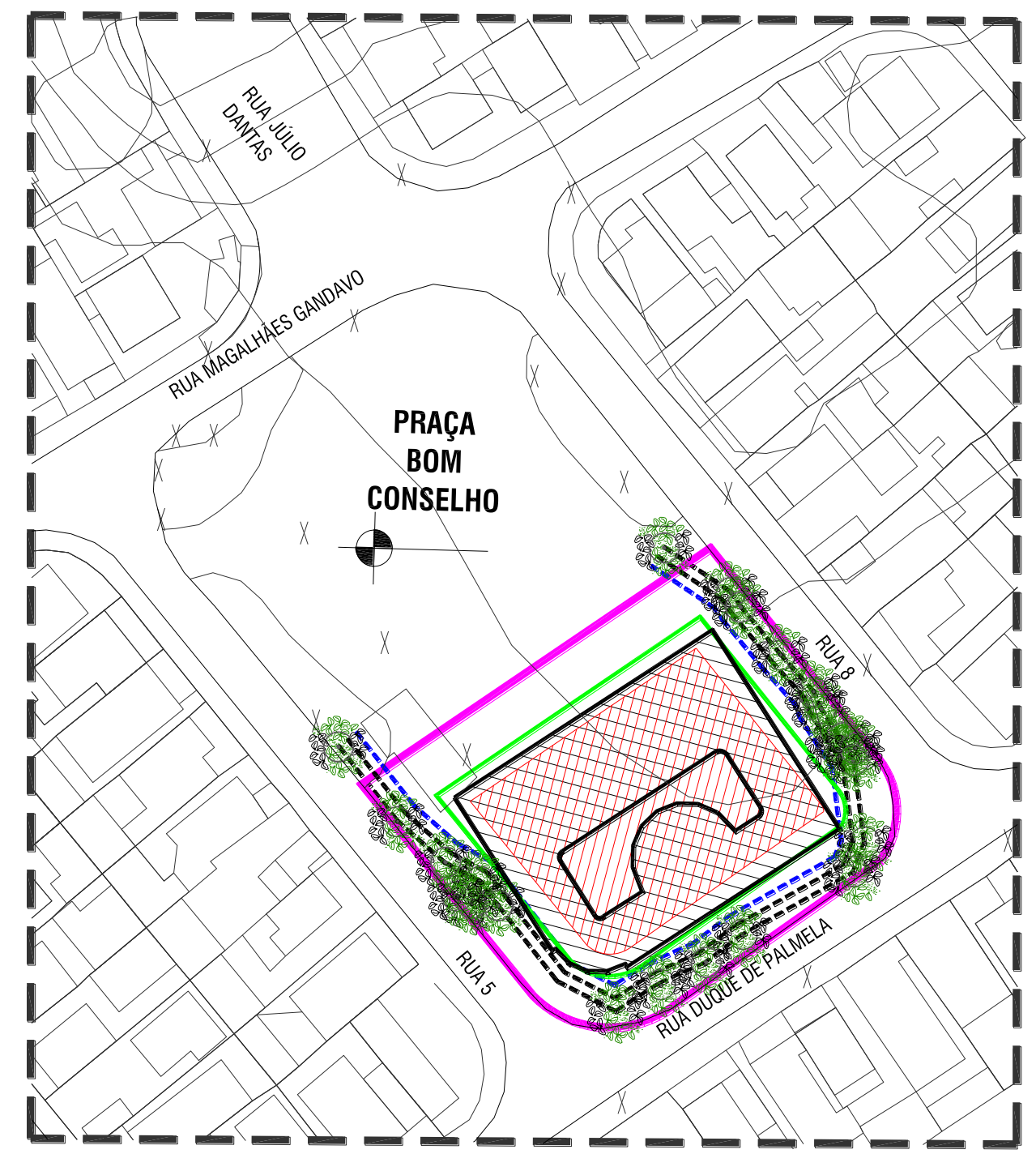

Figura 19 - Comparação entre a proposta da pesquisa e a real ocupação Fonte: Arte sobre cadastral - Autora (outubro de 2018)

\section{CONSIDERAÇÕES FINAIS}

A pesquisa concluiu que as ocupações de praças ocupadas por clínicas da família e outros equipamentos públicos carecem de instrumentos que garantam um menor impacto desse tipo de utilização do espaço livre público.

Criticaram-se as implantações das clínicas ou qualquer outro equipamento nas praças, no entanto a realidade tem demonstrado que nas últimas décadas isso se tornou muito comum e a fim de que essas implantações tenham seus efeitos negativos minimizados estabelecemos alguns critérios a serem observados. A técnica batizada de "Três 'Ds'" estabelece que deve haver: delimitação de no máximo metade do espaço livre público destinado ao lazer; delimitação dos recuos baseado nos indivíduos arbóreos do passeio e demarcação dos afastamentos de no mínimo $3 \mathrm{~m}$ em todos os lados.

Dessa forma, pretendeu-se mitigar os danos provenientes dessas ocupações que ocorrem cada vez com maior frequência nos espaços livres da cidade, espalhando módulos de arquitetura temporária, mas que permanecem durante anos impactando a paisagem urbana. 
Diante desse contexto, torna-se imperativa a melhor proteção da paisagem urbana, não só consonante com as questões ambientais, mas também no sentido de prover o cidadão de lugares adequados à prática do lazer e das relações de convívio social. Nesse contexto, cabe reafirmar que a praça é um espaço livre público destinado a uma função do ordenamento territorial, tem uma função social e essa função deve ser respeitada e valorizada como um bem jurídico da polis em benefício da sua população.

\section{AGRADECIMENTOS}

Ao Grupo SEL-RJ pelas contribuições inestimáveis no estudo sobre os espaços livres públicos na Cidade do Rio de Janeiro.

\section{REFERÊNCIAS}

ALEXY, Robert. Direitos Fundamentais, Ponderação e Racionalidade. Revista de Direito Privado. São Paulo: RT, n² 24, p. 334-344, out./dez. 2005.

AMARAL Daniela, SANCHEZ, Fernanda. e BIENENSTEIN, Regina. O Leste Fluminense, o COMPERJ e a questão urbano-habitacional in: Grandes Projetos Metropolitanos : Rio de Janeiro e Belo Horizonte / Fabricio Leal de Oliveira (org.) .... [et al.]. - Rio de Janeiro. Letra Capital, 151-186. 2012.

MENEZES, Ana Paula; MENDONÇA, Bruno R.; TÂNGARI, Vera R. Quando a praça vira...: estudos de caso sobre a ocupação das praças na cidade do Rio de Janeiro. In Cadernos do Desenvolvimento Fluminense, vol. 13, Rio de Janeiro: UERJ/CEPERJ, 2018, p. 81-98.

PREFEITURA DA CIDADE DO RIO DE JANEIRO. Plano Diretor de Desenvolvimento Urbano Sustentável do Município do Rio de Janeiro. Rio de Janeiro: PCRJ, 2011.

QUEIROGA, Eugenio. A megalópole e a praça: o espaço entre a razão de dominação e a razão comunicativa. (Tese de Doutorado). São Paulo: FAUUSP, 2001.

ROBBA, Fabio.; MACEDO, Silvio. S. Praças brasileiras. São Paulo: Editora da Universidade de São Paulo - Imprensa Oficial do Estado, 2002.

SARMENTO, Daniel. A Ponderação de Interesses na Constituição Federal. 1. ed. Rio de Janeiro: Lúmen Juris, 2003.

SILVEIRA, Vinicius L. M. Ponderação e Proporcionalidade no Direito Brasileiro. Conteúdo Jurídico, Brasília-DF: 23 abr. 2013. Disponível em:

$<$ http://www.conteudojuridico.com.br/?artigos\&ver=2.431 17\&seo=1>. Acesso em: 15 maio 2018.

ZEISEL, John. Inquiry by design: tools for environment-behavior reseach. New York: Cambrigde University Press, 1984. 